\title{
Shallow marine Rostroconchia (Mollusca) from the latest Devonian (Strunian) and their significance for rostroconch life style and evolution
}

\begin{abstract}
Michael R. W. AMLER
Institut für Geologie und Mineralogie, Universität zu Köln, Zülpicher Str.49a, D-50674 Köln, Germany; michael.amler@uni-koeln.de.

ABSTRACT. The rostroconch fauna of the uppermost part of the Devonian (Strunian, "Etroeungt") comes from a sand-/siltstone succession of the northern flank of the Velbert Anticline, western Germany. The few specimens most probably represent one species of the Hippocardioidea and one of the Conocardioidea without definite determination. The material confirms the difficulties in recognizing different shell layer architecture in conocardiid rostroconchs. The presence of rostroconchs in the Strunian documents a continuous evolutionary lineage from the abundant Middle Devonian rostroconch assemblages to the even more abundant rostroconch associations of the Mississippian. Three hippocardiid specimens are preserved in former life position with the anterior part of the conch oriented almost vertically within the sediment and the hood almost parallel with the former sediment surface, thus, perfectly confirming earlier suggestions on hippocardiid life style.
\end{abstract}

KEYWORDS: Hippocardioidea, Conocardioidea, morphology, life position, taphonomy, latest Famennian, D/C boundary, Germany

\section{Introduction}

The late Famennian sedimentary succession in central and western Europe is characterized by regressive sequences, followed by a short transgressive phase, the TR cycle IIf of Johnson et al. (1986) Strunian in age. This final Devonian pulse in the global sea-level curve is mirrored by respective litho- and biofacies within the siliciclastic shelf areas bounding the southeastern margin of Laurussia. This shelf is represented by a narrow, continuous band of siliciclastic, mixed siliciclastic-calcareous and calcareous sediments, in its central part known as the Condroz Shelf, recorded from southern Ireland across southwest England (north Devon), the northern Ardennes (Belgium) and the Bergisches Land (western Germany) further east to northern Poland. Although variable in specific lithology, the shallow subtidal environment of this shelf area was termed as the PiltonVelbert Facies, subdivided into several regional subfacies (see e.g. Van Steenwinkel, 1984, 1990; Thorez \& Dreesen, 1986; Matyja, 1988; Amler, 1995, 2001; Thorez et al., 2006 for details).

Due to the semi-arid to subtropical climate, the southeastern margin of Laurussia offered optimal conditions to establish a highly diverse fauna and flora during the latest Famennian transgressive phase contrasting with the sparse fauna of the nearshore middle and late Famennian. Somewhat variable substrate conditions, however, combined with other ecologically significant parameters, e.g. salinity, bottom currents, oxygen content and temperature, characterize contemporaneous faunal assemblages, mostly dominated by brachiopods and ostracodes, locally complemented by corals, crinoids, bryozoans and benthic mollusks (see e.g. Poty, 1999 for rugose corals). From the biofacies perspective, nature and physical properties of the substrate were of particular importance for the composition and diversity of these nearshore faunas. Inferred from fossil and sedimentary evidence, closely coexisting hard grounds, firm grounds and soft grounds enabled varying associations, episodically reformed due to variable clastic input from the adjacent land masses.

The rostroconchs studied for this contribution are a very minor component of the Pilton-Velbert (bio)facies and were collected from sedimentary rocks of the Ratingen - Velbert area (east of Düsseldorf, western Germany) at the northern flank of the Velbert Anticline, the northwesternmost structure of the Rhenohercynian Zone of the Rheinisches Schiefergebirge (Rhenish Massif). Modern studies are limited to a small number of exposures and disused quarries in the Ratingen - Velbert region since the area is densely populated and built-up. Furthermore, facies restrictions of biostratigraphic index fossils cause problems in the correlation of strata, especially near the Devonian-Mississippian Boundary (see below).

The history of geological research of the Velbert Anticline is discussed at length by Paeckelmann (1913), Paul (1939), Böger (1962) and Michels (1986). Noteworthy is the still fragmentary state of stratigraphical and palaeontological knowledge of the area despite one hundred years of investigation, especially, if compared with the closely related Belgian sequences (see e.g. Bultynck \& Dejonghe, 2001; Streel et al., 2006; Thorez et al., 2006 and references therein).

The present study is based on our ongoing study on palaeobiology, taxonomy and evolution of rostroconchs started in the 1980s (see recent references by Amler, Richter, Rogalla and colleagues) for the preparation of the forthcoming Treatise on Invertebrate Paleontology, Vol. Rostroconchia.

\section{Stratigraphic background}

The geology and palaeontology of the Famennian-Mississippian transition (Strunian to Hastarian) of the Velbert Anticline has been studied since mid- $19^{\text {th }}$ century and in the $20^{\text {th }}$ century mostly within the context for definition of the Devonian-Carboniferous (D/C) Boundary. The strata across the D/C Boundary exposed in some former quarries and other outcrops between Ratingen and Velbert (see e.g. Paul, 1939) includes the easternmost surface exposures of the shallow (proximal) subtidal facies that continues westward across Belgium to southwestern England (north Devon). Facies conditions and the lack of biostratigraphic valuable fossils hamper the precise biostratigraphic interpretation of the sequence compared with the well-known high-resolution conodont and ammonoid biostratigraphy of the late Devonian basinal and deep subtidal Cypridina Shale and cephalopod limestone facies (Dasberg and Wocklum stages) of central Europe. Details on the regional geology and stratigraphy are discussed for example in Paeckelmann (1913), Paul (1939), Böger (1962), Amler et al. (1994) and Amler \& Heidelberger (2003).

The stratigraphic basis for the region was established by Paul (1939) for the uppermost Devonian part and by Böger (1962) and Conil \& Paproth (1968) for the overlying Lower Carboniferous part. The lithology of the succession has been described at length by several authors (e.g. Paul, 1939; Amler et al., 1994). It is composed mostly of alternating micaceous, clayey-calcareous siltstones and greenish to ochreous siltstones interfingered by cm-thick sandstone and calcareous sandstone beds. Generally, fossils occur in single layers, some of which are very fossiliferous; certain beds yield monospecific layers, e.g. of plant remains, brachiopods or ophiuroids. The upper part of the unit is characterized by very fossiliferous clayey or calcareous siltstones. The fauna, in total, includes crinoids, brachiopods, bryozoans, corals, trilobites and bivalves as well as very rare gastropods and rostroconchs. For this sand-/siltstone unit, Paul (1939) introduced the term "Angertal-Schichten", equivalent with the Etroeungt (s.s.) original stratigraphic position. Paul's subdivision of the Etroeungt into three units $(\mathrm{E} \alpha, \mathrm{E} \beta$, and $\mathrm{E}$ $\gamma)$, later refined by Goldring (1957) based on brachiopods, was not applied to the Velbert region (Michels, 1986) and has not been correlated with the type Etroeungt in Belgium. The guide brachiopods display different ranges in western and eastern 
Europe which causes difficulties in the correlation with other fossil groups (Mottequin et al., 2014 and references therein; see also Streel et al., 2006).

In consequence, precise biostratigraphic data for the Ratingen - Velbert area are lacking. Only parts of the succession were dated, however, based on different fossil groups. Goniatites are almost absent except for one specimen of Cyrtoclymenia sp. (Michels, 1986). According to Price \& House (1984) cyrtoclymeniids persist until "late Strunian" time. The occurrence of the trilobites Phacops (Omegops) sp. ("Phacops accipitrinus accipitrinus Phillips" of authors), Pseudowaribole (Ps.) quaesita Hahn \& Brauckmann and Brachymetopus (B.) drevermanni Hahn indicates latest Devonian age as all three taxa are not known in Lower Mississippian strata (Hahn et al., 1988; Brauckmann et al., 1993). The conodonts Bispathodus ultimus, Bispathodus ziegleri, Bispathodus costatus and Bispathodus bispathodus were recorded from the lower part of the unit only (Michels, 1986), hence, this part correlates with the Middle to Upper costatus Zone or the Lower to Middle praesulcata Zone, respectively. Spores and foraminifers from this section have not as yet been re-studied satisfactorily, although successfully undertaken in Belgium for the respective strata (Higgs et al., 2013).

The overlying oolitic sequence is very poor in conodonts and lacks indicative fossils (Franke et al., 1975). Its presumed age ("Tn $1 \mathrm{~b}$ " or Early Hastarian, respectively) is only indirectly confirmed by the fauna of the succeeding Tournais Zwischenschiefer (Pontd'Arcole Formation; Amler \& Herbig, 2006, see also Paproth et al., 1983). Therefore, the sand-/siltstone unit is of latest Devonian age and the $\mathrm{D} / \mathrm{C}$ Boundary is still drawn within the middle or upper part of the oolitic unit, as already suggested by Böger (1962).

\section{On the fauna near the $\mathrm{D} / \mathrm{C}$ Boundary in the Velbert area}

The majority of fossils from the upper and uppermost Famennian sand-/siltsone units of the Ratingen - Velbert area has been studied by the working group on the "Fauna des deutschen Unterkarbon" (1930-1932) originally assuming earliest Carboniferous age. Paul (1939) presented a revised fossil list. Michels (1986) analyzed the palaeoecology without taxonomic revision of the fauna. As mentioned above most of the beds are poor in fossils, whereas single beds yield a rich fauna. Brachiopods are the most important element; they show a relatively high diversity and amount to more than $50 \%$ of all individuals. The second important group is ostracodes with up to $30 \%$ of the total fauna and a relatively low diversity. Bryozoans, especially members of the Fenestrata, are common and all other groups occur as minor faunal elements (1-2\%) reaching importance in single layers only (e.g. bivalves, ophiuroids, crinoids; see Michels, 1986 and Amler, 1995, 1996a for details).

\section{Rostroconchs in Strunian strata}

The study of conocardiid rostroconchs, i.e. the taxa of the order Conocardiida, superfamilies Conocardioidea and Hippocardioidea (see Amler \& Rogalla, 2004; Rogalla \& Amler, 2006c), is linked with bivalve taxonomy, as previously the Rostroconchia were thought to be uncommon, bizarre bivalves of rather doubtful systematic position (Branson et al., 1969) or even bivalved arthropods. Their status as a separate class of the Mollusca was introduced by Pojeta et al. (1972). After a first survey on the peculiar morphology of the group and a preliminary systematic arrangement (Pojeta \& Runnegar, 1976) many more details were discovered (see e.g. Pojeta, 1987; Rogalla, 2005 and references therein). Whereas the widely known type species of the genus Conocardium Bronn, 1835, Conocardium aliforme (J. de C. Sowerby, 1827), as such also the type of the Conocardiidae and the Conocardioidea, is still under revision, the members of the Hippocardioidea are well studied (e.g. Amler, 1996b; Rogalla, 2005; Rogalla \& Amler, 2006a, 2006b, 2006c, 2006d, 2007). Although morphological differences between Hippocardioidea and Conocardioidea are as yet not precisely defined (recent studies by M. Amler, K. Pfennings, University of Cologne), they are basically distinguished till present by the presence (Hippocardioidea) or absence (Conocardioidea) of the characteristic hood (see below).

Members of the Conocardiida possess a bilaterally symmetrical adult conch developed from a univalved larval shell, whose right and left halves or semi-conchs grow into two inflated valve-like shelly parts (pseudo bivalved), superficially resembling the valves of the Bivalvia. These halves are not "valves" in the strict (bivalve) sense, although this term is generally still in practice, because they do not correspond to the valves of the Bivalvia in anatomy and function. As the general molluscan bauplan (i.e. dorsal visceral mass, antero-ventral foot, mantle, mantle cavity, gills) is accepted for rostroconchs, the univalved cap-shaped protoconch is situated at the straight dorsal margin, where continuous shell layers (at least one) connect the both halves of the conch. Consequently, hinge teeth and ligamental structures for articulation and opening as well as adductor muscles for closure are not developed. The anterior, posterior and ventral commissure is always closed, except for well-defined permanent gapes designed for interaction between the animal and the environment. The shell is composed of three architectural layers of variable and complex microstructure and ornamentation.

The adult conch of most Conocardiida is divided into three areas: 1) the anterior prolonged snout with the snout gape, 2) the globose, often triangular central body posteriorly truncated and 3 ) the flattened posterior rostral area with the tubular rostrum (Fig. 1). Hippocardioids additionally possess a hood (French: éventail; German: Schleppe) composed of one shell layer only which surrounds the rostral area. Based on the basic molluscan bauplan and the demand for feeding and locomotion, the larger gape of the shell margin (snout) is considered as anterior end, analogous to bivalves and scaphopods, because only here the foot - in bivalves and scaphopods situated close to the mouth could have been extruded. Thus, the rostrum - invariably placed opposite to the snout - is considered as posterior end and together with the orifice, a small, single posteroventral opening, served for respiratory demands (Fig. 1). Details on the morphology, research history and taxonomy were published in Amler \& Rogalla (2004, 2007, 2013) and Rogalla (2005).

The last accounts on bivalves of the region, as mentioned above originally the host taxon for conocardiids, was given by Paul $(1939,1941,1954)$ based on own material and collections of Kayser (1882), Drevermann (1902) and Paeckelmann (1913). In his survey on the Etroeungt, he cited only the specimen listed by Paeckelmann (1913) as Conocardium sp. (BGR.X12334), here re-studied and figured (Fig. 2). Neither Bärtling \& Paeckelmann (1928) nor Wunstorf (1931) in their survey and mapping of sheets Kettwig (today GK25 4607 Heiligenhaus) and Velbert (GK25 4608) mentioned any rostroconchs. In his summary on "Etroeungt" bivalves, Paul (1954) listed 45 bivalve taxa and one rostroconch (Conocardium alaeforme) without description.

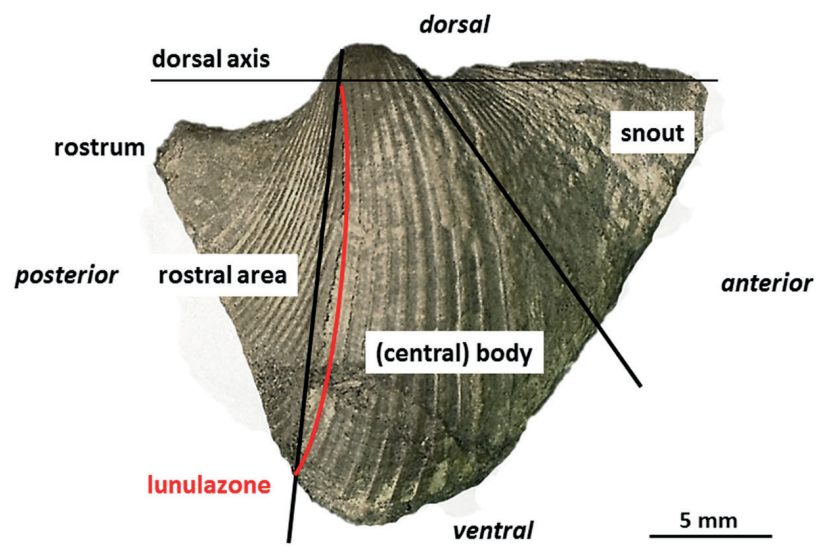

Figure 1. Rostroconch morphology and terminology as used in the text, based on Conocardium sp., aff. C. truncatum Fraipont in de Koninck, 1885; BGR.X12335, coll. W. Wunstorf; right lateral view. Note the attachment line of the hood (not preserved) indicated by lunular growth lines and termed "lunulazone" herein. 
Michels (1986) also simply listed Conocardium sp. and Amler, after a first brief summary on the bivalve fauna (Amler et al., 1990; Amler, 1993) revised this group except for the rostroconchs (Amler, 1995, 1996a).

From corresponding strata and regions in southwest England, i.e. the Pilton Shales and the Baggy Sandstone, no conocardiids have as yet been mentioned (Phillips, 1841; Whidborne, 18961907; Edmonds et al., 1985) and this also is the case for the Etroeungt of Belgium (Dehée, 1929; Demanet, 1958; Streel et al., 2006).

\section{Palaeontological descriptions}

\subsection{Material and preservation}

Within the last two decades nearly 40 collections worldwide for detailed rostroconch and bivalve studies have been visited. Apart from occasional, mostly private collections, latest Famennian rostroconchs were rarely sampled. As rostroconchs are faciesspecific organisms, the group was rather ignored during the sampling campaigns for a definition of the D/C Boundary. At present, only ten specimens of different preservation from the Velbert area are at hand.

The studied material has different sources: first, the former private collection of E. Thomas, now housed at the Senckenberg Natural History Museum and Research Institute, Frankfurt am Main, Germany. This material was sampled during construction work of the A44 across the former quarries "Am Wasserfall" north of Velbert (for details see Amler, 1993). Second, material has been collected during the stratigraphical and palaeontological survey in the period between 1910 and 1935, a.o. the campaign on the fauna of the Lower Carboniferous ("Die Fauna des deutschen Unterkarbon"). Within this context, Henry Paul (1909-1944) collected fossil material from various lower Carboniferous and latest Devonian outcrops in central Europe. He also studied and revised material from many institutions and museums collected earlier and published prior to 1935, e.g. by Drevermann (1902), Paeckelmann (1913) and Wunstorf (1931), although not mentioned in these publications (for locality details see Paul, 1939, pp. 666, 683, 687). Third, samples collected during mapping campaigns by E. Paproth from the Geological Survey of Northrhine-Westphalia (GD/NRW), Krefeld, from temporary outcrops at Lilienstraße, Velbert-Neviges (Table 1).

The following prefixes to specimen numbers are used: BGR - Bundesanstalt für Geowissenschaften und Rohstoffe Hannover, Außenstelle Berlin, Germany; GD/NRW - Geologischer Dienst Nordrhein-Westfalen, Krefeld, Germany; SMF - Senckenberg
Forschungsinstitut und Naturmuseum Frankfurt am Main, Germany.

Preservation of rostroconchs is quite variable and mostly controlled by various factors, such as shell mineralogy, host rock matrix and permeability, diagenetic processes etc. By contrast to bivalves, but similar to brachiopods, most rostroconchs are preserved with both "valves" in original position and contact because the continuous dorsal shell layer prevents a gaping of the "valves" and, thus, disarticulation after death as in bivalves (see Rogalla et al., 2003; Rogalla, 2005; Amler \& Rogalla, 2007 for details). Fragile parts of the shell are often fragmented; distal parts of the hood, the most anterior portion of the snout as well as the rostrum are often broken off or damaged (Figs 2-3) due to post-mortem transportation. Pre-depositional as well as synand post-diagenetic processes have frequently altered the external shell surface morphology, thus, most specimens display different modes of preservation, sometimes even in a single specimen (Fig. 3 ). In conocardiids from carbonate environments shell material is mostly recrystallized, whereas specimens from siliciclastic facies are usually preserved as external moulds (Fig. 4) and steinkerns (Figs 5-7) lacking characters of the shell.

All these features apply to the few studied specimens, hence, combination of steinkerns, external moulds and incomplete shelly specimens requires detailed and proper knowledge of the hippocardiid anatomy (see Rogalla, 2005; Rogalla \& Amler, 2006b). The very complex shell architecture relative to the shell microstructure (Amler, 1996b; Rogalla et al., 2002, 2003) does not allow direct comparison of internal rib ornamentation as displayed by the steinkern with probable external or medial layer ornamentation as seen in shelly specimens. Thus, specimen BGR.X12335 (Fig. 3) allows complementing comparison where the posterior portion of the central conch shows the broad radial ribbing of the internal shell layer, overlain by shell material of the middle and external layer without distinct radial ornament. Instead, the external shell layer is ornamented with comarginal growth lines of variable strength only.

By contrast with the shell of the median conch, the hood is formed by one shell layer only (Amler, 1996b; Rogalla, 2005). Internal details of the hood's shell microstructure have as yet not been described adequately, as the shell material in most of the fossils is recrystallized. However, as can be observed in several specimens from different localities and stratigraphic levels, a radial structure crossed by comarginal elements of micro- to mesoscopic scale is often preserved (Rogalla \& Amler, 2006b). In steinkerns and moulds, these rather quadratic to trapezoidal elements can be seen as equivalent dots (Figs 4, 5A, C, 6). A similar preservation pattern was described for specimens of

\begin{tabular}{|c|c|c|c|c|}
\hline Institution & Collection & Coll No. & Preservation & Locality \\
\hline \multirow{5}{*}{$\begin{array}{l}\text { Geologischer Dienst } \\
\text { Nordrhein-Westfalen, } \\
\text { Krefeld }\end{array}$} & E. Paproth & GD/NRW.Fa101 & steinkern, ventral view & Lilienstraße, Velbert-Neviges \\
\hline & E. Paproth & GD/NRW.Fa102 & steinkern, right view & Lilienstraße, Velbert-Neviges \\
\hline & E. Paproth & GD/NRW.Fa103 & steinkern, left view & Lilienstraße, Velbert-Neviges \\
\hline & E. Paproth & GD/NRW.Fa104 & mould, ventral view & Lilienstraße, Velbert-Neviges \\
\hline & E. Paproth & GD/NRW.Fa105 & $\begin{array}{l}\text { steinkern, ventral view; fragment of } \\
\text { mould }\end{array}$ & Lilienstraße, Velbert-Neviges \\
\hline \multirow{3}{*}{$\begin{array}{l}\text { Senckenberg } \\
\text { Forschungsinstitut und } \\
\text { Naturmuseum Frankfurt }\end{array}$} & E. Thomas & SMF.VLA.64 & steinkern, ventral view & Velbert-Langenhorst \\
\hline & E. Thomas & SMF.VLA.65A, B & steinkern, ventral view, mould & Velbert-Langenhorst \\
\hline & E. Thomas & SMF.VLA.67A, B & steinkern, anteroventral view, mould & Velbert-Langenhorst \\
\hline \multirow{2}{*}{$\begin{array}{l}\text { Bundesanstalt für } \\
\text { Geowissenschaften und } \\
\text { Rohstoffe, Außenstelle } \\
\text { Berlin }\end{array}$} & W. Paeckelmann & BGR.X12334 & shell, complete, damaged & $\begin{array}{l}\text { Buchmühle, Angertal near } \\
\text { Heiligenhaus }\end{array}$ \\
\hline & W. Wunstorf & BGR.X12335 & shell, right view & Farbhaus near Heiligenhaus \\
\hline
\end{tabular}

Table 1. Repository, collection numbers and preservation of the Strunian rostroconchs from the Velbert Anticline studied for this contribution. 
Ordovician or Silurian age (Amler \& Bartholomäus, 1998; Amler \& Gummersbach, 2015).

Whereas the steinkerns from the Velbert locality display the proper relationships of median conch (body) to the hood, the two shelly specimens from "Etroeungt" strata of Ratingen and Heiligenhaus do not have the hood preserved. Its former presence, however, is undoubtedly indicated by the radial band of the hood attachment onto the rostral area, where the shell material
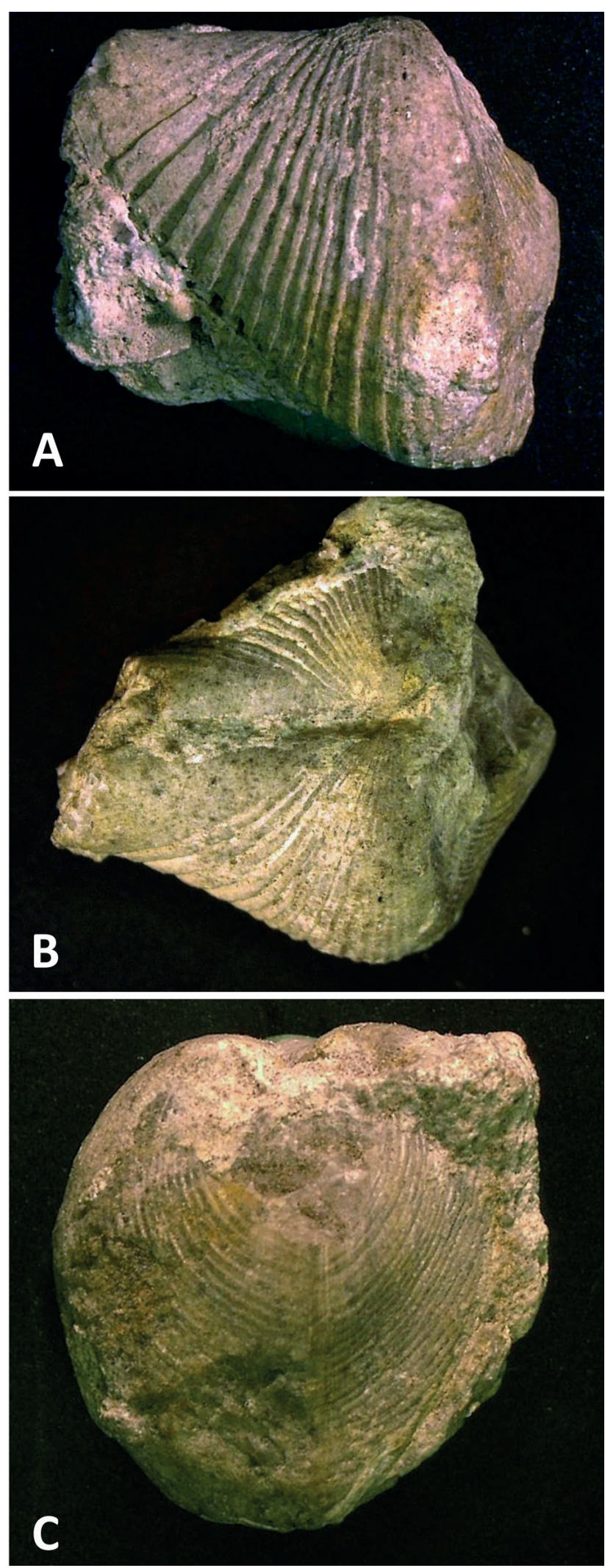

Figure 2. Conocardium sp., aff. C. truncatum Fraipont in de Koninck, 1885; BGR.X12334, coll. W. Paeckelmann, from Buchmühle, Angertal near Heiligenhaus, Velbert Anticline. A. Left lateral view; B. Dorsal view; C. Posterior view, rostrum broken off. Specimen size: length $22 \mathrm{~mm}$, width 20 $\mathrm{mm}$, height $20 \mathrm{~mm}$. of the hood originally was connected with the shell of the median conch. This band is directly preserved by lunulate growth lines within a weakly impressed furrow developed from the tip of the umbo to the ventralmost point of the "valve" (Fig. 1, red line, Fig. 3; see also Rogalla, 2005). This connection band superficially reminds of a weakly developed selenizone in archaeogastropods and is termed "lunulazone" herein.

The size, i.e. the width, of the hood is traced by specimens SMF.VLA.64 and VLA.65 (Figs 5, 6), where the relations of the width of the hood to the diameter of the rostral area can be estimated as almost $1: 1$. The anterior part of the conch is prepared ventrally, including left and right lateral sides, but the dorsal part is still embedded in the matrix (Figs 5A, C, 6). Consequently, both specimens show the anterior part of the animal as a steinkern plus the posterior surface of the hood as external mould in the matrix; the posterior view of the rostral area is hidden within the matrix and cannot be prepared without damage of the specimen.

Based on their preservation, the studied specimens can be separated into two groups characterized by distinctly differing morphology. All of them have a general compact triangular outline with a short, cone-shaped (brevicone) conch and the anterior snout not markedly separated from the median shell body (Figs 2-3, 5-6). In specimens SMF.VLA.64 and VLA.65 and GD/NRW. Fa101 (Figs 5-6) the ventral and anteroventral margins are nearly straight and lead to a typical hippocardiid appearance, whereas specimens BGR.X12334 and X12335 (Figs 2-3) have a separated convex margin of the median body and a straight anteroventral part merging with the snout and leading to a rather conocardiid shape. Thus, in the shelly specimens the median body can be distinguished from the anterior portion of the conch, whereas the steinkerns show a continuous triangular body-snout conch (Figs 5-6). Anteriorly, the snout opens into a suboval aperture which extends V-shaped ventrally into the ventral commissure (Fig. 5A, C). Restrictions by apertural (or marginal) denticles as observed elsewhere are not visible in the studied material. The umbos are strongly incurved and somewhat raised above the dorsal margin (Figs 1-3). From the posterior truncated part of the umbo, a sharp keel, the body carina sensu Rogalla (2005; or primary carina of authors) runs ventrally, separating the truncated rostral field (posterior conch area; Fig. 2C) from the median shell body (Figs 1, 3A).

The most striking feature of the specimens is the development of the hood, a sheet-like structure projecting distally from the body carina, thus surrounding the complete rostral area and leading to a "soup plate" appearance of the posterior shell region in posterior view. This is perfectly preserved in the steinkernexternal mould specimens, but seen in anterior view (Figs 5A, 6). Specimens SMF.VLA.64 and VLA.65 completely show the external mould of the posterior surface of the hood in the rock matrix and the anterior view of the central and anterior conch in steinkern preservation (Figs 5A, 6). By contrast to many other taxa, the rostral field in BGR.X12334 and X12335 is raised tentlike, elevated to the posterior commissure, biparting the rostral area and joining the elevated base of the rostrum (Figs 1, 2A, B, $3 \mathrm{~A})$. From the dorsal part of the rostral field, the rostrum originally projects as a smoke-stack- or funnel-shaped tube broken-off in all the specimens at hand (Figs 1-3).

Apart from the snout and the rostrum, the third, very small aperture, the ventral foramen (= ventral orifice of authors) forming a narrow tube at the ventral commissure of the hood is developed in steinkern preservation in specimen SMF.VLA.65 (Fig. 5A, C).

All Conocardioida possess a shell structure which is different from that of bivalves or gastropods (Amler, 1996b; Rogalla et al., 2002, 2003). Especially in the hippocardiids, a peculiar and as yet not really understood architecture and microstructure occurs, where architectural layers do not correspond to microstructural layers. Generally, the shell is thick except for the hood which remains quite fragile, constructed of one shell layer only. At least three shell layers of different architecture, microstructure and ornamentation are developed in the central conch and the snout (Figs 2A, B, 3A, B). The inner and middle layers are radially ribbed in differing strength, whereas the outer shell layer is almost smooth, reticulate or comarginally striated with growth lines. Due to the contrasting preservation, the specimens SMF. 

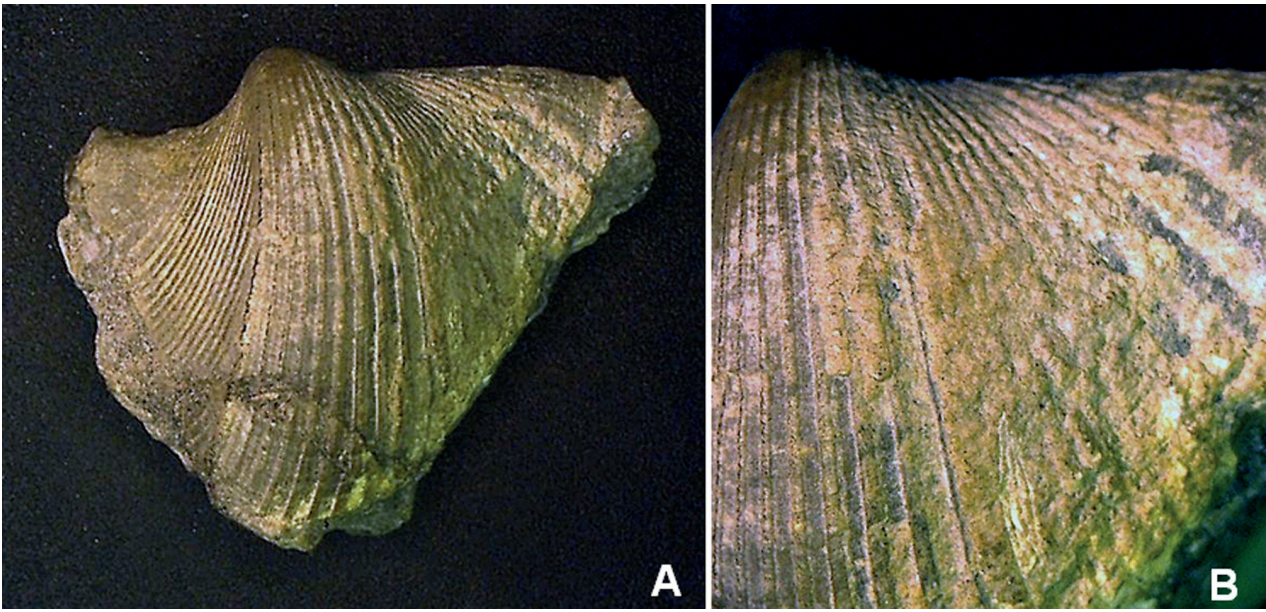

Figure 3. Conocardium sp., aff. $C$. truncatum Fraipont in de Koninck, 1885; BGR.X12335, coll. W. Wunstorf, from Farbhaus near Heiligenhaus, Velbert Anticline. A. Right lateral view; B. Close-up of central body and part of snout region; note weathered or abraded external shell layer upon middle layer. Specimen size: length 20 $\mathrm{mm}$, height $16 \mathrm{~mm}$.

VLA.64, VLA.65 and GD/NRW.Fa101 show the weathered external surface of the middle or inner shell layer, whereas the shelly specimen BGR.X12334 and X12335 (Figs 2,3) and the silicone cast of the external mould GD/NRW.Fa104 (Fig. 4) show remains and the ornamentation of the outer shell layer (for comparison, see e.g. Amler \& Lohrengel, 2015).

\subsection{Taxonomy and comparison}

At the moment, proper taxonomic assignment remains uncertain because no species has as yet been described from the latest Famennian near-shore environments (Whidborne, 1896-1907; Drevermann, 1902; Dehée, 1929). The few specimens at hand do not allow complete reconstruction and, hence, description of new species. Unfortunately, the bulk of species described by de Koninck (1885) for supposed (lower) Tournaisian strata cannot be assigned to precise lithostratigraphy, hence, all the species labelled by de Koninck (1885) as "Tournaisian of Tournay" can be, in fact, of late Tournaisian or even Viséan age. As the type specimens are completely removed from rock matrix, subsequent age determinations by foraminifers or conodonts are impossible.

The two rather complete specimens with shell preservation from "Etroeungt" strata (BGR.X12334, X12335) may externally be compared with Conocardium truncatum Fraipont in de Koninck (1885, p. 106, pl. 20 figs 32-34, pl. 41 figs 24-27). Both are rather equal in size with the de Koninck material (eight syntypes for comparison were available) and obviously show the same shell layer morphology, i.e. not the external(most) shell surface. Equally ornamented by 6-7 radial ribs of similar width and height on the median conch and 4-5 broad ribs on the snout region, the Velbert specimens may tentatively be assigned to this species. These two specimens had already been observed by Paul (1939) in his survey on the "Etroeungt" of western Europe. Specimen BGR.X12334 was previously described as Conocardium sp. by Paeckelmann (1913, p. 261; cited also in Paul, 1939, p. 666). Although Paul was urged to assign the faunal elements as precise as possible, he left the two specimens under open nomenclature ("Conocardium sp."). The material was listed in his Etroeungt study (Paul, 1939) and his stratigraphic summary on Lower Carboniferous bivalves (Paul, 1954, p. 43) where he also included latest Devonian, i.e. Etroeungt and Strunian occurrences. But his assignment to Conocardium alaeforme (J. de C. Sowerby, 1827) (today = aliforme; see Amler \& Rogalla, 2004) is definitely wrong, as current studies by M. Amler and K. Pfennings (University of Cologne) have shown. Nevertheless, based on present knowledge, the two specimens may be assigned to the genus Conocardium Bronn, 1835 and, thus, represent the conocardioid lineage.

The brevicone steinkerns SMF.VLA.64, VLA.65 and GD/ NRW.Fa101, Fa104 from Velbert are rather similar to Fraipontia tournaisense $($ Branson, 1942) $=$ Conocardium antiquum Fraipont in de Koninck (1885, p. 118, plate 20 figures 38-40; preoccupied; see Rogalla \& Amler, 2006b, 2006d), but the specimens may not represent their original length/height proportions due to compaction and slight tectonic compression. Undoubtedly, based on the presence of a wide hood, the specimens - albeit their specific determination - are typical members of the Hippocardiidae (see Rogalla \& Amler, 2006b).

\subsection{Observations of the former rostroconch life position}

The facies distribution of conocardiid rostroconchs most probably was controlled by various factors such as nutrient supply, facies stability, salinity, grain size, oxygen content, water temperature etc., but only few of them as yet well understood. Based on morphological variation in anatomical characters and palaeobiological constraints derived from the basic molluscan bauplan, it is plausible that several life styles were realized for occupation of different niches, e.g. reef margin, soupy mud or unstable sand. Thus, the morphology of many Conocardiida reflects their life habits, and basic morphotypes infer mobile epibenthic crawling, immobile semi-endobenthic sedimentsticking, and the loss of the hood in advanced conocardiids indicates a rather mobile, almost endobenthic life position (Runnegar, 1978; Pojeta, 1987; Richter \& Amler, 1995; Amler \& Richter, 1997; Rogalla, 2005; Amler \& Rogalla, 2013). Consequently, some taxa occurred widespread in unstable and variable facies realms, whereas others were probably restricted to specific habitats but without indicative characters.

We have explained elsewhere, mostly based on palaeophysiological reasons and palaeobiological constraints, that hippocardiid rostroconchs obtained a specific life position relative to the sediment (substrate) surface (Richter \& Amler, 1995; Rogalla, 2005; Amler \& Rogalla, 2013). With respect to mobility, stable position within the substrate and efficient

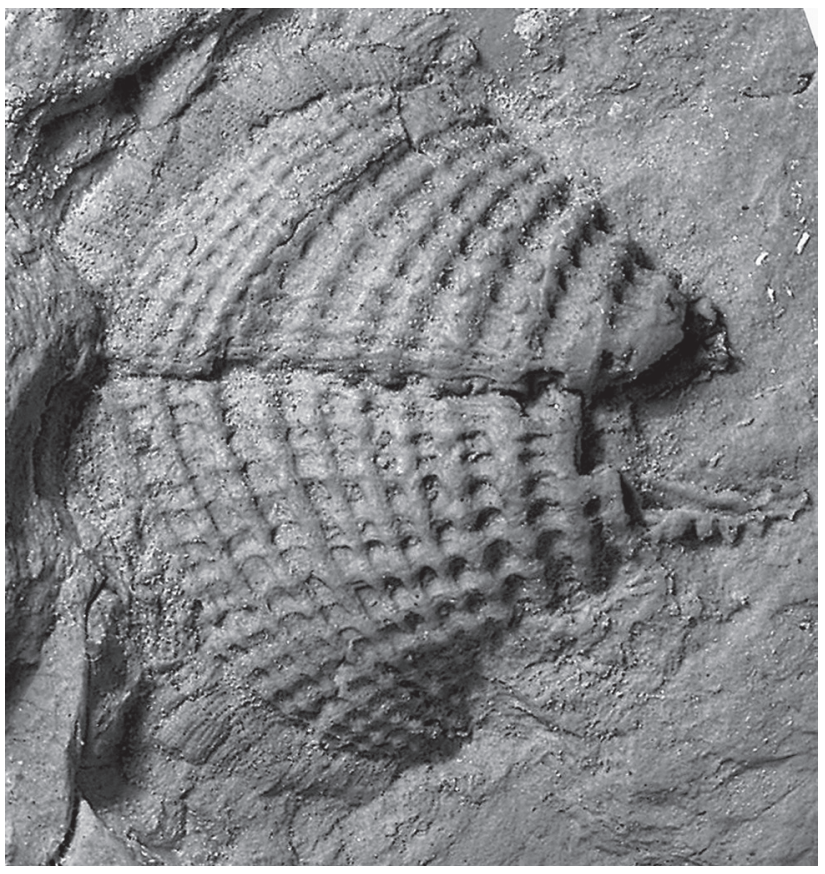

Figure 4. "Hippocardia" sp., aff. Fraipontia tournaisense (Branson, 1942) = Conocardium antiquum Fraipont in de Koninck, 1885; artificial cast of external mould GD/NRW.Fa104, coll. E. Paproth, from Lilienstraße, VelbertNeviges; anteroventral view. Note the relatively coarse reticulate external shell ornamentation. Specimen size: length $17 \mathrm{~mm}$. 
Figures 5. "Hippocardia" sp., aff. Fraipontia tournaisense (Branson, 1942) $=$ Conocardium antiquum Fraipont in de Koninck, 1885. 5A-C. Steinkern of body and external mould of posterior surface of the hood SMF. VLA.65B, coll. E. Thomas, from Velbert-Langenhorst. 5A. Oblique anteroventral view; 5B. Right lateral view; 5C. Anterior view, showing the hood almost parallel to the bedding plane and the snout directed vertical into the substrate. Specimen size (without hood): length $7 \mathrm{~mm}$, height $10 \mathrm{~mm}$; width of hood 10 $\mathrm{mm}$; specimen slightly deformed. D. Steinkern GD/NRW.Fa101, coll. E. Paproth, from Lilienstraße, Velbert-Neviges; anteroventral view. Specimen size: length $15 \mathrm{~mm}$.
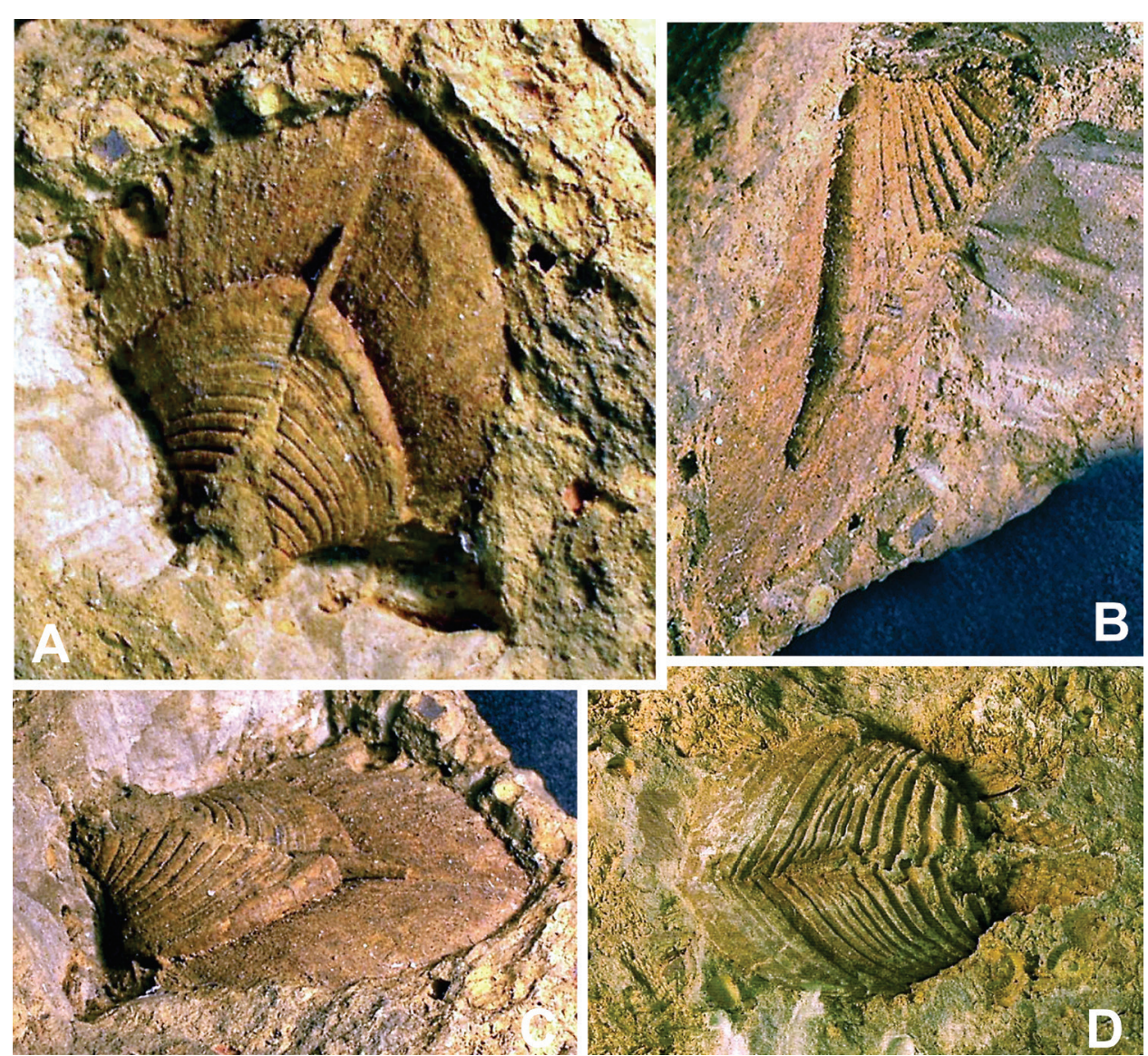

orientation of the posterior surface of the hood one life position only is able to maintain each of the demands properly (Fig. 8). In consequence, this life habit leads to a relatively sluggish mobility, if at all. In fact, the relatively large diameter of the posterior (rostral) area plus the hood was hardly suitable for rapid or even moderate locomotion, even if the grain size of the sediment offered sufficient pore space for grain movement. The well-suited physical conditions of the sediment for burrowing activities, however, are well supported by the presence of associated heteroconch bivalves such as Paracyclas, Schizodus, Siliquimya, Pleurophorella, Sanguinolites etc (Amler, 1996a). Thus, hippocardiid burrowing or locomotion, respectively, was completely opposite to scaphopod locomotion due to rather contrasting length-width relationships of the conch.

From the trophic perspective, conocardioid rostroconchs conventionally have been interpreted as suspension feeders or detritus feeders without properly considering morphological constraints. Suspension feeding, i.e. feeding by filtration of particulate organic matter analogous to bivalves, as one of the possible basic trophic strategies for rostroconchs would require inhalant water through the rostrum filtered by gills of unknown type and exhalant water ejected through the orifice. However, suspension feeding as the sole feeding type can be excluded due to the unsuitable cross-section size of both the rostrum and the orifice as well as the questionable evolutionary level of the gills. By contrast, detritus feeding, i.e. feeding by collecting organic particles with the aid of anterior mantle extensions or captaculae comparable with scaphopods, but without their ability to locomotion due to the shell structures (rostrum, hood), also can be excluded as the sole feeding type due to the immobility of the animal caused by the hood. Hence, we presented an alternative interpretation of the life habit for hippocardioid rostroconchs (Rogalla \& Amler 2005a, 2005b) by farming of photosymbionts, i.e. feeding on the products of photosynthesis of the zooxanthellae accommodated within the soft body analogous with Recent species of Corculum or Fragum or within the mantle analogous with Recent members of the Tridacnidae. Unfortunately, zooxanthellae are not likely to be preserved in the fossil record, thus, a palaeophotosymbiosis can be traced by circumstantial evidence and palaeobiological constraints only. These include devices for light exposure of the tissue that accommodate the zooxanthellae (either by microstructural features of the shell or by additional carpeting surface for the extruding mantle tissue), indication of increased calcification rate by shift of the chemical balance through photosymbionts in favour of calcification (e.g. gigantism, increased shell thickness) and particular environmental conditions which enable a symbiosis (constant water temperature always above $20^{\circ} \mathrm{C}$, clear and well translucent water and low rate of sedimentation, shallow water depth) and which occur in (sub-) tropical regions up to maximum $30^{\circ} \mathrm{N}$ and $\mathrm{S}$ latitude only (Jones et al., 1968; Seilacher, 1990).

The three Velbert specimens are obviously preserved in former life position (Figs 5, 6, 8). As reported elsewhere for the late Ordovician (Amler \& Gummersbach, 2015; Amler \& Lohrengel, 2015) and the Middle Mississippian (Amler, 1996b) hippocardiids can be preserved in life position, if the hood, originally oriented almost parallel with the sediment surface, is embedded accordingly. In consequence, the median body of the specimens and the snout were directed downward almost vertical into the substrate (Fig. 8). This orientation does hardly allow preservation of the rostrum - in that perfectly autochthonous position almost vertically oriented into the water column and, thus, broken off. These specimens directly support the proposed life styles suggested earlier (Amler \& Rogalla, 2007, 2013) and also confirmed for Ordovician hippocardioids (Amler \& Gummersbach, 2015).

Although the Velbert specimens SMF.VLA.64, VLA.65, VLA.67 are preserved in the position described, minor postdepositional compaction of the sediment has altered the original orientation of the animals from almost vertical into more oblique, i.e. diagonal to the former sediment surface (Fig. 7). In consequence, the angle between the anterior surface of the hood and the ventral margin of the conch is rather expanded from originally about $120-130^{\circ}$ to $>150^{\circ}$.

Apart from comparison of the Velbert specimens with examples of preserved life orientation of different age there are good arguments for validation of the assumed life position. The studied rostroconchs are directly associated with bivalves, brachiopods and bryozoans sometimes even in the same bedding plane. Both the latter taxa offer further evidence by their own 
preservation patterns. An associated athyrid brachiopod is preserved bivalved with the articulated posterior margin and the two umbos downward, almost perpendicular to the sediment surface (see Michels, 1986, p. 86), completely similar to the hippocardiid position anterior downward next to that specimen (Fig. 7). The associated bryozoans are typical members of the order Fenestrata developing net- or sieve-like fronds. After death of the colonies, these nets, or fragments of them, were embedded parallel to the sediment surface. Specimen SMF.VLA.64 shows the large fragment of a fenestrate colony parallel to the mould of the hippocardiid hood providing evidence of the former sediment surface at the time of burial of both fossils (Fig. 6).

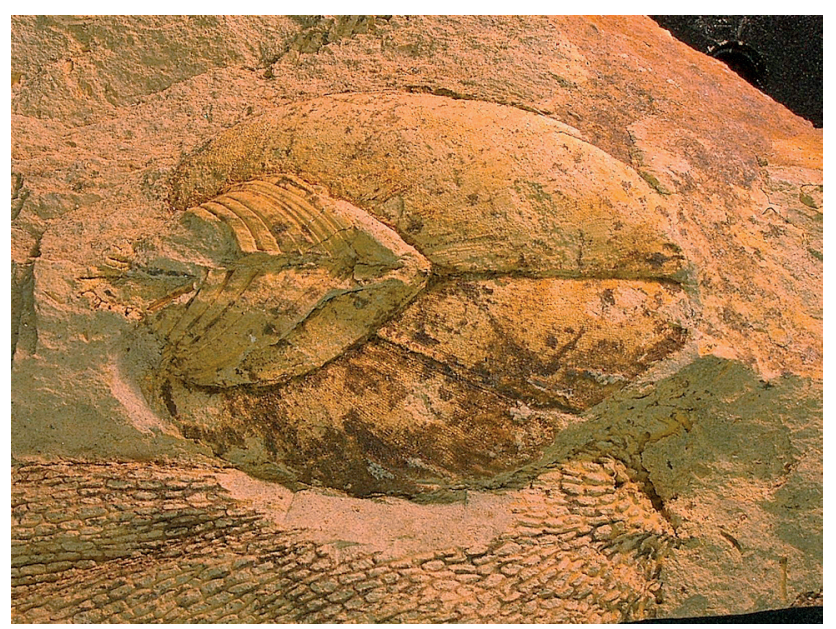

Figure 6. "Hippocardia" sp., aff. Fraipontia tournaisense (Branson, 1942) = Conocardium antiquum Fraipont in de Koninck, 1885; steinkern SMF. VLA.64, coll. E. Thomas, from Velbert-Langenhorst; anterior view, showing the hood almost parallel to the bedding plane and the snout directed vertical into the substrate. Note the posterior external mould of the hood showing details of the former shell microstructure and the large bryozoan frond preserved parallel to the bedding plane. Specimen size: width $10 \mathrm{~mm}$; width of hood $16 \mathrm{~mm}$; specimen slightly compressed and deformed.

\subsection{The evolutionary perspective of Strunian rostroconchs}

Most of the Middle Devonian rostroconch taxa are based on rather ill preserved type material and many of the various species introduced, e.g. by Whidborne (1892-1907), Beushausen (1895) and Hall (1884-1885), turned out to be nomina dubia (Rogalla \& Amler, 2006d, 2007). Only few localities of Eifelian to Givetian strata offer rich and nicely preserved specimens. However, the general aspect emphasizes a rather moderate to reasonably high abundance of rostroconchs from Middle Devonian up to Early Late Devonian time. The Kellwasser Crisis appears to have cut down rostroconch diversity rapidly and dramatically. The last multispecific and abundant rostroconch faunas are recorded from the terminating subreefal environments of early Frasnian age (Whidborne, 1892-1907; Beushausen, 1895). The Matagne Shale of late Frasnian age appears to be almost void of Conocardioidea and Hippocardioidea (Maillieux, 1936) and this also seems to be the case for the Early Famennian ("Nehdenian") Knoppenbissen Formation in west-central Europe (Jux \& Krath, 1974). The Refrath borehole assemblage (mostly "Dasbergian" in age; Amler, 2004) although quite rich in (endobenthic) bivalves did not yield rostroconchs either and the late Devonian cephalopod limestone facies was probably unsuitable, i.e. too deep, for hippocardiid rostroconchs. Time-equivalent strata from North America (McAlester, 1962) do not yield rostroconch taxa, nor were they recorded from Poland. Although generally the Condroz Facies would favour hippocardiid occurrences, the preservation potential in these sandstones does not. It is, however, rather surprising that survey in the type region of the Pilton (-Velbert) Facies, e.g. Phillips (1841), Whidborne (1896-1907), Edmonds et al. (1985), did not record any rostroconch.

Within this scenario, the occurrence of - at least - two species of conocardiids and hippocardiids in the Pilton-Velbert Facies of Velbert is a very important document for a continuous evolutionary

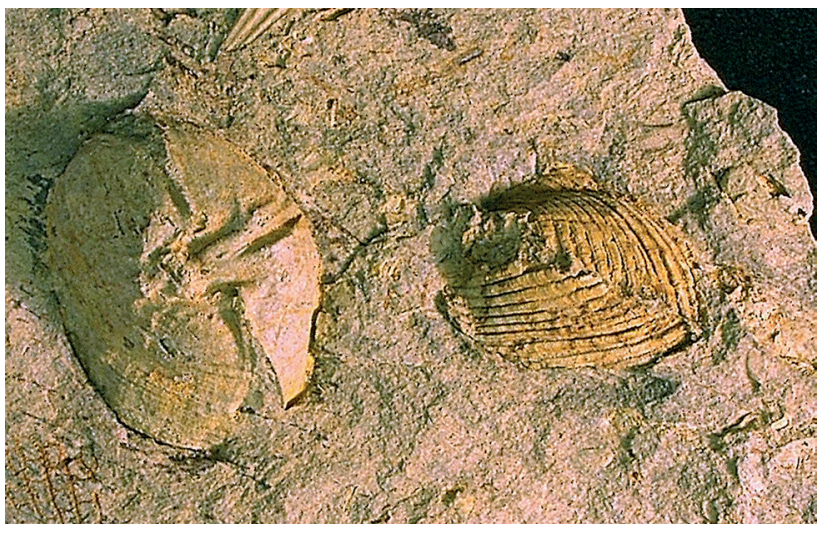

Figure 7. "Hippocardia" sp.; steinkern SMF.VLA.67, coll. E. Thomas, from Velbert-Langenhorst; anteroventral view. Note the posterior part of athyrid brachiopod and the anteroventral part of the hippocardiid rostroconch, respectively, both preserved perpendicular to the bedding plane. Specimen size: width $7 \mathrm{~mm}$

lineage from the abundant Middle Devonian assemblages to the Mississippian assemblages of distinctly greater abundance. Even if the Hangenberg Crisis affected many groups significantly (Kaiser et al., 2016), conocardiids and hippocardiids survived this extinction event. Although this development was already visualized in Sepkoski's famous spindle diagram, the details were as yet hardly documented.

Furthermore, the specimens from the shallow shelf facies document the evolutionary trend in hippocardiids towards a general increase in conch size from the Ordo-Silurian through the Devonian to Mississippian time. Late Early Palaeozoic members of the Hippocardioidea, i.e. Pseudobigaleaidae (see Rogalla \& Amler, 2006a; Amler \& Lohrengel, 2015) were rather small-sized animals (1-2 cm conch length), although already equipped with a relatively large hood up to double conch height. In the Devonian siliciclastic and calcareous shallow shelf environments, specimen size grew up to 5-8 cm conch length (see e.g. Hall, 1884-1885; Rogalla \& Amler, 2006b, 2006c; Beushausen, 1895; Halfar, 1882; Whidborne 1892-1907) with an equivalent hood - conch ratio. This tendency is also mirrored in the Velbert specimens. The peak in hippocardiid specimen size development, however, was reached in the Middle Mississippian (Viséan) with individual size up to $10 \mathrm{~cm}$ conch length and height plus proportionally giant hood width in Hippocardia hibernica (J. Sowerby, 1815), Hippocardia herculea (de Koninck, 1885) and Globocardia koninckii (Baily, 1873) (Amler, 1996b; Rogalla \& Amler, 2006b, 2006c).

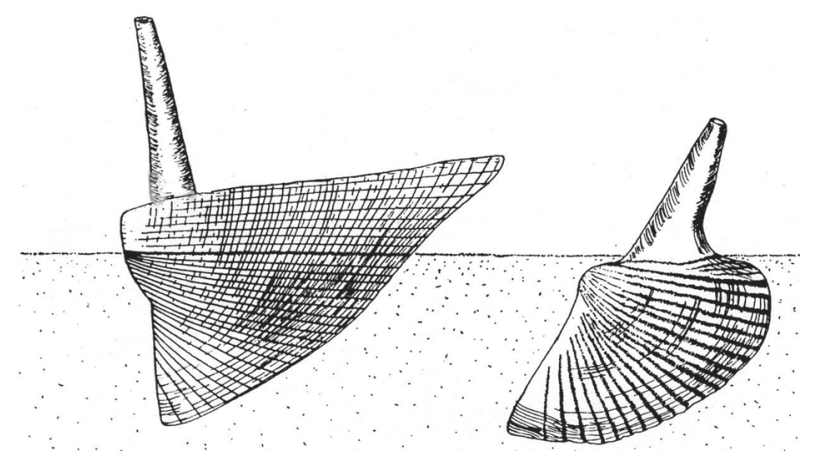

Figure 8. Basic types of life position in hippocardioid (left) and conocardioid (right) rostroconchs (adapted from Amler \& Rogalla, 2013). 


\section{Summary and Conclusions}

1. The few specimens from different strata and different localities of latest Devonian, i.e. Strunian, age undoubtedly allow detailed even though not complete reconstruction and description of a typical conocardiid and a hippocardiid taxon from the DevonianCarboniferous transition sequence of west-central Europe. I refrain from erecting new species due to the lack of proper type specimens. None of the specimens at hand offers the possibility of a description of all relevant diagnostic features, thus, a species should be named subsequently after discovery of sufficiently preserved material.

2. The presence of conocardiid and hippocardiid rostroconchs in siltstones from the shallow subtidal Pilton-Velbert facies documents continuous evolutionary lineages from the abundant Middle Devonian rostroconch assemblages to the even more abundant rostroconch associations of the Early and Middle Mississippian for Conocardioidea and Hippocardioidea.

3. The specimens also document the general evolutionary increase in specimen size from the Silurian and early Devonian to the Middle Mississippian.

4. The specimens observed support all our earlier proposals of hippocardiid life position relative to the sediment surface, not only by palaeobiological constraints, but also by the preservation patterns as well as additional evidence through associated bryozoan fronds embedded parallel to the sediment surface and brachiopods in former life position.

5. In consequence, the preservation of the hippocardiids in (autochthonous) life position allows precise evidence that the sediments of the Pilton-Velbert facies were deposited within a relatively calm, non-turbulent, but well-lighted (euphotic) subtidal zone suitable for the presumed photoautotrophic symbionts (Rogalla, 2005; Rogalla \& Amler, 2005a, 2005b) in hippocardiid rostroconchs.

6. The specimens support all earlier views towards the palaeoecological significance of hippocardiid rostroconchs for an occupation of shallow subtidal environments due to the function of the hood.

7. Morphology of the two shelly specimens closely resembles that of Mississippian conocardioid taxa, hence, the same evolution pattern as in bivalves is visible, i.e. the new diversification started already with the Late Famennian (Strunian) transgression prior to the earliest Mississippian. The specimens display "modern", i.e. Late Palaeozoic, conocardiid characters that are characteristic for the Tournaisian and Viséan taxa of the Carboniferous Limestone Facies.

\section{Acknowledgements}

It is a pleasure to acknowledge the help and advice of the following colleagues: E. Thomas (Ribnitz-Damgarten) provided the specimens from Velbert-Langenhorst; A. Ehling (Berlin) gave access to the collections of the BGR Berlin-Spandau and M. Piecha to the collections of the Geologischer Dienst NordrheinWestfalen, Krefeld. D. Weyer (Berlin) assisted with information; C. Brauckmann (Clausthal-Zellerfeld) and A. Nützel (Munich) reviewed the manuscript and, finally, the editors of Geologica Belgica gave helpful comments.

\section{References}

Amler, M.R.W., 1993. Shallow marine bivalves at the Devonian/ Carboniferous Boundary from the Velbert Anticline (Rheinisches Schiefergebirge). In Streel, M., Sevastopulo, G.D. \& Paproth, E. (eds), The Devonian-Carboniferous Boundary - a final report of the International Working Group on the Devonian-Carboniferous Boundary. Annales de la Société Géologique de Belgique, 115, 405423.

Amler, M.R.W., 1995. Die Bivalvenfauna des Oberen Famenniums West-Europas. 1. Einführung, Lithostratigraphie, Faunenübersicht, Systematik 1. Pteriomorphia. Geologica et Palaeontologica, 29, 19143.

Amler, M.R.W., 1996a. Die Bivalvenfauna des Oberen Famenniums West-Europas. 2. Evolution, Paläogeographie, Paläoökologie, Systematik 2. Palaeotaxodonta und Anomalodesmata. Geologica et Palaeontologica, 30, 49-117.
Amler, M.R.W., 1996b. Giant hippocardiids from the Lower Carboniferous of Western Europe. Irish Journal of Earth Sciences, 15, 113-122.

Amler, M.R.W., 2001. Evolution of Late Devonian Biofacies in the South Laurussian Shelf. $15^{\text {th }}$ International Senckenberg Conference 2001, Frankfurt/M. Abstracts, 2.

Amler, M.R.W., 2004. Late Famennian bivalve, gastropod and bellerophontid molluscs from the Refrath 1 Borehole (Bergisch Gladbach-Paffrath Syncline; Ardennes-Rhenish Massif, Germany). Courier Forschungsinstitut Senckenberg, 251, 151-173.

Amler, M.R.W. \& Bartholomäus, W.A., 1998. Ein hippocardiider Rostroconch in einem Hornstein (Ordosilur) von Sylt. Archiv für Geschiebekunde, 2, 387-397.

Amler, M.R.W. \& Gummersbach, K., 2015. Ein pseudobigaleaider Rostroconch aus dem ober-ordovizischen Boda-Kalkstein des SiljanGebietes (Mittel-Schweden). Archiv für Geschiebekunde, 7, 311323.

Amler, M.R.W. \& Heidelberger, D., 2003. Late Famennian Gastropoda from south-west England. Palaeontology, 46, 1151-1211.

Amler, M.R.W. \& Herbig, H.-G., 2006. Ostrand der Kohlenkalk-Plattform und Übergang in das Kulm-Becken im westlichsten Deutschland zwischen Aachen und Wuppertal. In Deutsche Stratigraphische Kommission (Koord./Red.: M.R.W. Amler \& D. Stoppel) (eds), Stratigraphie von Deutschland 6: Unterkarbon (Mississippium). Schriftenreihe der Deutschen Gesellschaft für Geowissenschaften, 41, 441-477.

Amler, M.R.W. \& Lohrengel, A.F., 2015. Ein pseudobigaleaider Rostroconch in einem ober-ordovizischen Geschiebe. Archiv für Geschiebekunde, 7, 261-276.

Amler, M.R.W. \& Richter, E., 1997. Conocardium und Hippocardia Ernährungs- und Habitatspezialisten unter den Rostroconchien? Programm der 67. Jahrestagung der Paläontologischen Gesellschaft, Daun 1997. Terra Nostra, 1997, 18-19.

Amler, M.R.W. \& Rogalla, N.S., 2004. History and nomenclature of the Conocardioidea (Mollusca: Rostroconchia). Paläontologische Zeitschrift, 78, 307-322.

Amler, M.R.W. \& Rogalla, N.S., 2007. "Moderne" Rostroconchien: Conocardium und Hippocardia. Fossilien, 2007, 149-154.

Amler, M.R.W. \& Rogalla, N.S., 2013. Biogeographical distribution patterns in Early Palaeozoic Rostroconchia (Mollusca). In Harper, D.A.T. \& Servais, T. (eds), Early Palaeozoic Biogeography and Palaeogeography. Geological Society, London, Memoirs, 38, 235255.

Amler, M.R.W., Thomas, E., Weber, K.M. \& Wehking, S., 1990. Bivalven des höchsten Oberdevons im Bergischen Land (Strunium; nördliches Rhein. Schiefergebirge). Geologica et Palaeontologica, 24, 41-63.

Amler, M.R.W., Rathmann, S. \& Richter, E., 1994. Henry Pauls „Etroeungt-Schichten“ des Bergischen Landes - Biostratigraphie und Biofazies am Nordrand des Velberter Sattels. Archäologie im Ruhrgebiet, 1994, 73-98.

Baily, W.H., 1873. Remarks on the genus Pleurorhynchus, with a description of a new species. Journal of the Royal Geological Society of Ireland, 13, New Series 3, 24-25.

Bärtling, R. \& Paeckelmann, W., 1928. Erläuterungen zur Geologischen Karte von Preußen und benachbarten deutschen Ländern. Blatt Velbert. Preußische Geologische Landesanstalt, Berlin, 1-109.

Beushausen, L., 1895. Die Lamellibranchiaten des rheinischen Devon mit Ausschluss der Aviculiden. Abhandlungen der KöniglichPreussischen Geologischen Landesanstalt, Neue Folge, 17, 1-514.

Böger, H., 1962. Zur Stratigraphie des Unterkarbons im Velberter Sattel. Decheniana, 114, 133-170.

Branson, C.C., 1942. Correction of homonyms in the lamellibranch genus Conocardium. Journal of Paleontology, 16, 387-392.

Branson, C.C., La Rocque, A. \& Newell, N.D., 1969. Order Conocardioida. In Cox, L.R., Newell, N.D., Branson, C.C., Casey, R., Chavan, A., Coogan, A.H., Dechaseaux, C., Fleming, C.A., Haas, F., Hertlein, L.G., Keen, A.M., La Rocque, A., McAlester, A.L., Perkins, B.F., Puri, H.S., Smith, L.A., Soot-Ryen, T., Stenzel, H.B., Turner, R.D. \& Weir, J. Systematic descriptions. In Moore, R.C. \& Teichert, C. (eds), Treatise on Invertebrate Paleontology, Part N, Mollusca 6, 1-3 (Bivalvia). The University of Kansas Press and Geological Society of America, Lawrence, Kansas and Boulder, Colorado, N859-N860.

Brauckmann, C., Chlùpác, I. \& Feist, R., 1993. Trilobites at the DevonianCarboniferous boundary. In Paproth, E., Sevastopulo, G.D. \& Streel, M. (eds), The Devonian-Carboniferous Boundary - a final report of the International Working Group on the Devonian-Carboniferous Boundary. Annales de la Société Géologique de Belgique, 115, 507-518.

Bronn, H.G., 1834-1838. Lethaea Geognostica oder Abbildungen und Beschreibungen der für die Gebirgs-Formationen bezeichnendsten Versteinerungen, 1. Übergangs- bis Oolithengebirge. 1. edit., vi + 1350 p., atlas 16 p., 47 pls; Stuttgart (E. Schweizerbart) [1. Lief.: 1-48, pls 2, 4-8 (1834); 2. Lief.: 49-192, pls 1, 3, 9-12 (1835); 3.-4. Lief.: 193-224, pls 13-24 (1835); 5. Lief.: 225-480, pls 25-30 (1836); 6.-8. Lief.: 481-768, pls 31-47 (1837); 9.-10. Lief.: 769-1350 (1838)]. 
Bultynck, P. \& Dejonghe, L., 2001. Devonian lithostratigraphic units (Belgium). In Bultynck P. \& Dejonghe L. (eds), Lithostratigraphic scale of Belgium. Geologica Belgica, 4, 39-69.

Conil, R. \& Paproth, E., 1968. Mit Foraminiferen gegliederte Profile aus dem nordwest-deutschen Kohlenkalk und Kulm. Decheniana, 119, 51-94.

Dehée, R., 1929. Description de la faune d'Etroeungt. Mémoires de la Société Géologique de France, N.S., 11, 1-62.

Demanet, F., 1958. Contribution à l'étude du Dinantien de la Belgique. Mémoires de 1'Institut Royal des Sciences Naturelles de Belgique, $141,1-151$

Drevermann, F., 1902. Ueber eine Vertretung der Etroeungt-Stufe auf der rechten Rheinseite. Zeitschrift der Deutschen Geologischen Gesellschaft, 54, 480-524.

Edmonds, E.A., Whittaker, A. \& Williams, B.J., 1985. Geology of the country around Ilfracombe and Barnstaple. Memoir geological sheets 277 and 293, New Series. Memoirs of the British Geological Survey, London, $97 \mathrm{p}$

Franke, W., Eder, W. \& Engel, W., 1975. Sedimentology of a Lower Carboniferous Shelf-margin. Neues Jahrbuch für Geologie und Paläontologie, Abhandlungen, 150, 314-353.

Goldring, R., 1957. The last toothed Productellinae in Europe (Brachiopoda, Upper Devonian). Paläontologische Zeitschrift, 31, 207-228.

Hahn, G., Hahn, R. \& Brauckmann, C., 1988. Die Trilobiten des belgischen Kohlenkalkes (Unter-Karbon). 10. Biostratigraphie. Geologica et Palaeontologica, 22, 55-72.

Halfar, A., 1882. Ueber ein grosses Conocardium aus dem Devon des Oberharzes. Zeitschrift der Deutschen Geologischen Gesellschaft, $34,1-11$.

Hall, J., 1884-1885. Natural History of New York. Palaeontology 5 (1). Lamellibranchiata 2, descriptions and figures of the Dimyaria of the upper Helderberg, Hamilton, Portage and Chemung groups. Geological Survey of New York, Albany, N.Y., i-lxii, 269-561.

Higgs, K.T., Prestianni, C., Streel, M. \& Thorez, J., 2013. High resolution miospore stratigraphy of the Upper Famennian of eastern Belgium, and correlation with the conodont zonation. Geologica Belgica, 16, 84-94.

Johnson, J.G., Klapper, G. \& Sandberg, Ch.A., 1986. Late Devonian eustatic cycles around margin of Old Red Continent. Annales de la Société géologique de Belgique, 109, 141-147.

Jones, D.S., Williams, D.F. \& Spero, H.J., 1988. More light on photosymbiosis in fossil mollusks: the case of Mercenaria "tridacnoides". Palaeogeography, Palaeoclimatology, Palaeoecology, 64, 141-152.

Jux, U. \& Krath, J., 1974. Die Fauna aus dem mittleren Oberdevon (Nehden-Stufe) des südwestlichen Bergischen Landes (Rheinisches Schiefergebirge). Palaeontographica (A), 147, 115-168.

Kaiser, S.I., Aretz, M. \& Becker, R.T., 2016 (in press). The global Hangenberg Crisis (Devonian-Carboniferous transition): review of a first-order mass extinction. In Becker, R.T., Königshof, P. \& Brett, C.E. (eds), Devonian Climate, Sea Level and Evolutionary Events. Geological Society, London, Special Publications, 423. doi. org/10.1144/SP423.9

Kayser, E., 1882. Beiträge zur Kenntnis von Oberdevon und Culm am Nordrande des Rheinischen Schiefergebirges. Jahrbuch der Königlich Preussischen Geologischen Landesanstalt und Bergakademie, 1881, 51-91.

Koninck, L.G. de, 1885. Faune du Calcaire Carbonifère de la Belgique. 5. Lamellibranches. Annales du Musée Royal d'Histoire Naturelle de Belgique, 11, 1-283.

Maillieux, E., 1936. La faune des schistes de Matagne (Frasnien Supérieur). Mémoires du Musée Royal d'Histoire Naturelle de Belgique, 77, 1-74.

Matyja, H., 1988. Famennian facies of Pomerania, northwestern Poland, and the paleogeography of Northern Europe. In McMillan, N.J., Embry, A.F. \& Glass, D.J. (eds), Devonian of the World. Proceedings of the Second International Symposium on the Devonian System. Canadian Society of Petroleum Geologists, Calgary, 2, 637-647.

McAlester, A.L., 1962. Upper Devonian Pelecypods of the New York Chemung Stage. Peabody Museum of Natural History, Yale University, Bulletin, 16, 1-88

Michels, D., 1986. Ökologie und Fazies des jüngsten Ober-Devon von Velbert (Rheinisches Schiefergebirge). Göttinger Arbeiten zur Geologie und Paläontologie, 29, 1-86.

Mottequin, B., Brice, D. \& Legrand-Blain, M., 2014. Biostratigraphic significance of brachiopods near the Devonian-Carboniferous boundary. Geological Magazine, 151, 216-228.

Paeckelmann, W., 1913. Das Oberdevon des Bergischen Landes. Abhandlungen der Königlich Preußischen Geologischen Landesanstalt, Neue Folge, 70, 1-356.

Paproth, E., Conil, R., Bless, M.J.M., Boonen, P., Bouckaert, J., Carpentier, N., Coen, M., Delcambre, B., Deprijck, C., Deuzon, S., Dreesen, R.
Groessens, E., Hance, L., Hennebert, M., Hibo, D., Hahn, G., Hahn, R., Hislaire, O., Kasig, W., Laloux, M., Lauwers, A., Lees, A., Lys, M., Opdebeek, K., Overlau, P., Pirlet, H., Poty, E., Ramsbottom, W., Streel, M., Swennen, R., Thorez, J., Vanguestaine, M., Van Steenwinkel, M. \& Vieslet, J.L., 1983. Bio- and lithostratigraphic subdivisions of the Dinantian in Belgium, a review. Annales de la Société Géologique de Belgique, 106, 185-239.

Paul, H., 1939. Die Etroeungt-Schichten des Bergischen Landes. Jahrbuch der Preußischen Geologischen Landesanstalt (for 1938), 59, 647-726.

Paul, H., 1941. Lamellibranchiata infracarbonica. Fossilium Catalogus. I. Animalia, 91, 1-348.

Paul, H., 1954. Die unterkarbonischen Muscheln des Rheinischen Schiefergebirges. Decheniana, 102 A, 39-45.

Phillips, J., 1841. Figures and descriptions of the Palaeozoic fossils of Cornwall, Devon, and West Somerset. Longman, Brown, Green \& Longmans, London, xii $+231 \mathrm{p}$.

Pojeta, J. Jr., 1987. Class Rostroconchia. In Boardman, R.S., Cheetham, A.H. \& Rowell, A.J. (eds), Fossil invertebrates. Blackwell Science Publications, Palo Alto, 358-380.

Pojeta, J. Jr. \& Runnegar, B., 1976. The palaeontology of rostroconch molluscs and the early history of the phylum Mollusca. United States Geological Survey, Professional Paper, 968, 1-88.

Pojeta, J. Jr., Runnegar, B., Morris, N.J. \& Newell, N.D., 1972. Rostroconchia: A new class of bivalved molluscs. Science, 177, $264-$ 267.

Poty, E., 1999. Famennian and Tournaisian recoveries of shallow water Rugosa following late Frasnian and late Strunian major crises, southern Belgium and surrounding areas, Hunan (South China) and the Omolon region (NE Siberia). Palaeogeography, Palaeoclimatology, Palaeoecology, 154, 11-26.

Price, J.D. \& House, M.R., 1984. Ammonoids near the DevonianCarboniferous Boundary. Courier Forschungsinstitut Senckenberg, $67,15-22$.

Richter, E. \& Amler, M.R.W., 1995. Wie lebte Conocardium? Überlegungen zur Lebensweise jungpaläozoischer Rostroconchia. Terra Nostra, 1995, 71 .

Rogalla, N.S., 2005. Paläobiologie und Systematik der neuen Überfamilie Hippocardioidea Pojeta \& Runnegar, 1976 (Rostroconchia, Mollusca). PhD thesis, Philipps University Marburg. 419 p. http:// archiv.ub.uni-marburg.de/diss/z2005/0515/pdf/dnsr.pdf

Rogalla, N.S. \& Amler, M.R.W., 2005a. Paläophotosymbiose - der Schlüssel zur Lebensweise hippocardioider Rostroconchia (Mollusca). Beitragskurzfassungen zur 75. Jahrestagung der Paläontologischen Gesellschaft 2005, Graz. Berichte des Instituts für Erdwissenschaften K-F-Universität Graz, 10, 106-107.

Rogalla, N.S. \& Amler, M.R.W., 2005b. Palaeophotosymbiosis - the key to understanding the life habit of hippocardioid Rostroconchia (Mollusca). 49 $9^{\text {th }}$ Annual Meeting 2005 at Oxford, Abstracts. Palaeontological Association Newsletter, 60, 55.

Rogalla, N.S. \& Amler, M.R.W., 2006a. Revision der Familie Pseudobigaleaidae Hoare, Mapes \& Yancey, 2002 (Mollusca; Rostroconchia). Paläontologische Zeitschrift, 80, 167-208.

Rogalla, N.S. \& Amler, M.R.W., 2006b. Revision der Familie Hippocardiidae Pojeta \& Runnegar, 1976 (Mollusca; Rostroconchia). Paläontologische Zeitschrift, 80, 238-276.

Rogalla, N.S. \& Amler, M.R.W., 2006c. Taxonomie und Systematik der Hippocardioidea Pojeta \& Runnegar, 1976 [n. superfam.] (Mollusca; Rostroconchia). Paläontologische Zeitschrift, 80, 344-383.

Rogalla, N.S. \& Amler, M.R.W., 2006d. Index of conocardioid and hippocardioid rostroconch taxa (Mollusca: Rostroconchia). Geologica et Palaeontologica, 40, 27-61.

Rogalla, N.S. \& Amler, M.R.W., 2007. Nomina dubia der Hippocardioidea (Mollusca; Rostroconchia). Paläontologische Zeitschrift, 81, 29-70.

Rogalla, N.S., Amler, M.R.W., Carter, J.G. \& Pojeta, J. jr., 2002. Schalenarchitektur und -mikrostruktur bei Conocardioidea (Rostroconchia, Mollusca). In Niebuhr B. (ed.), GEO 2002 Planet Erde: Vergangenheit, Entwicklung, Zukunft. Programm und Kurzfassungen. Schriftenreihe der Deutschen Geologischen Gesellschaft, 21, 280.

Rogalla, N.S., Carter, J.G. \& Pojeta, J. Jr., 2003. Shell microstructure of the Late Carboniferous rostroconch mollusc Apotocardium lanterna (Branson, 1965). Journal of Paleontology, 77, 655-673.

Runnegar, B., 1978. Origin and evolution of the class Rostroconchia. Philosophical Transactions of the Royal Society of London, B284, 319-333.

Seilacher, A., 1990. Aberrations in bivalve evolution related to photo- and chemosymbiosis. Historical Biology, 3, 289-311.

Sowerby, J., 1812-1815. The mineral conchology of Great Britain; or coloured figures and descriptions of those remains of testaceous animals or shells, which have been preserved at various times and depths in the earth, 1. 234 p. + index, pls 1-102, London (published by the author) [1-32, pls 1-9 (1812), 33-96, pls 10-44 (1813), 97-178, pls 45-78 (1814), 170-234, pls 79-102, index (1815)]. 
Sowerby, J. de C., 1826-1835. The mineral conchology of Great Britain; or coloured figures and descriptions of those remains of testaceous animals or shells, which have been preserved at various times and depths in the earth, 6. $230 \mathrm{p}$. + index, pls 504-609, London (published by the author) [1-86, pls 504-545 (1826); 87-156, pls 546-580 (1827); 157-200, pls 581-597 (1828); 201-230, pls 598-609; Index (1829), Systematic Index (1835)]

Streel, M., Brice, D. \& Mistiaen, B., 2006. Strunian. In Dejonghe, L. (ed.), Chronostratigraphic units named from Belgium and adjacent areas. Geologica Belgica, 9, 105-109.

Thorez, J. \& Dreesen, R., 1986. A model of a regressive depositional system around the Old Red Continent as exemplified by a field trip in the Upper Famennian "Psammites du Condroz" in Belgium. Annales de la Société Géologique de Belgique, 109, 285-323.

Thorez, J., Dreesen, R. \& Streel, M., 2006. Famennian. In Dejonghe, L. (ed.), Chronostratigraphic units named from Belgium and adjacent areas. Geologica Belgica, 9, 27-45.

Van Steenwinkel, M., 1984. The Devonian-Carboniferous boundary in the vicinity of Dinant, Belgium. Courier Forschungsinstitut Senckenberg, 67, 57-69.

Van Steenwinkel, M., 1990. Sequence stratigraphy from "spot" outcrops - example from a carbonate-dominated setting: DevonianCarboniferous transition, Dinant synclinorium (Belgium). In Aigner, Th. \& Dott, R.H. (eds), Processes and Patterns in Epeiric Basins. Sedimentary Geology, 69, 259-280.

Whidborne, G.F., 1892-1907. A monograph of the Devonian fauna of the South of England, 2. The fauna of the limestones of Lummaton, Wolborough, Chircombe Bridge, and Chudleigh. Palaeontographical Society Monographs, 45-47, 49, 1-214.

Whidborne, G.F., 1896-1907. A monograph of the Devonian fauna of the South of England. 3. The fauna of the Marwood and Pilton Beds of North Devon and Somerset. Palaeontographical Society Monographs, 36, 1-247.

Wunstorf, W., 1931. Erläuterungen zur Geologischen Karte von Preußen und benachbarten deutschen Ländern. Blatt Kettwig. Preußische Geologische Landesanstalt, Berlin, 1-84. 